\title{
Histogenic Process
}

National Cancer Institute

\section{Source}

National Cancer Institute. Histogenic Process. NCI Thesaurus. Code C21128.

A multicellular process involved in the formation of new, more mature, or differentiated cells or tissues. $(\mathrm{NCl})$ 